\title{
Catalytically active palladium pyridylidene complexes: pyridinium ionic liquids as $N$-heterocyclic carbene precursors
}

\author{
Martin Albrecht* ${ }^{* a}$ and Helen Stoeckli-Evans ${ }^{b}$ \\ Received (in Cambridge, UK) 10th June 2005, Accepted 27th July 2005 \\ First published as an Advance Article on the web 22nd August 2005 \\ DOI: 10.1039/b508225k
}

Pyridinium salts similar to those used as ionic liquid solvents readily undergo palladation in the presence of a base, thus giving palladium-pyridylidene $N$-heterocyclic carbene complexes that are active catalysts for Suzuki-type cross-coupling reactions.

Solvents are generally used to maximize the homogeneous distribution of reaction partners and to control and balance temperature effects throughout a reaction. In addition, they may accelerate reactions by stabilizing key transition states along the reaction coordinate through non-covalent interactions. However, they are considered to be chemically inert during reactions, that is, they are not subject to breaking and making of (covalent) bonds.

Recently, ionic liquids have been promoted as a novel class of solvents, ${ }^{1}$ since they combine a variety of advantages such as environmental friendliness (virtually no vapor pressure, easiness of recovery and recycling), physical robustness within a large temperature range, and high solubilization potential, e.g., for reactions catalyzed by metal nanoparticles. ${ }^{2}$ Most often, ionic liquids derived from imidazolium and pyridinium ions have been used, for example [bimim $]\left[\mathrm{BF}_{4}\right]$ and $[\mathrm{MePy}]\left[\mathrm{Cl}-\mathrm{AlCl}_{3}\right]$.<smiles></smiles>

$\left[\right.$ bimim] $\left[\mathrm{BF}_{4}\right]$

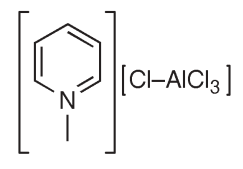

$[\mathrm{MePy}]\left[\mathrm{Cl}-\mathrm{AlCl}_{3}\right]$
Interestingly, imidazolium ionic liquids have also been used as precursors of $\mathrm{N}$-heterocyclic carbene ligands in organometallic chemistry. ${ }^{3}$ It has been shown that metallation of imidazolium salts can occur under mild conditions and in the absence of a base. ${ }^{4}$ These findings suggest that ionic liquids may act as reagents and not only as solvents in transition metal catalyzed reactions.

In contrast to imidazolium salts, pyridinium ionic liquids have been assumed to be resistant towards metallation. ${ }^{5}$ Their resistance can be rationalized by a comparatively low stabilization of the corresponding carbene by one nitrogen only. However, pyridylidene-type transition metal complexes have been proposed as products from $\mathrm{N}$-protonation and -alkylation of platinum group pyridyl complexes. ${ }^{6}$ In addition, similar complexes have

${ }^{a}$ Chemistry Department, University of Fribourg, Chemin du Musee 9, CH-1700 Fribourg, Switzerland. E-mail: martin.albrecht@unifr.ch; Fax: +41 26300 9738; Tel: +41263008786

${ }^{b}$ Institut de Chimie, Laboratoire de Cristallographie, Université de Neuchâtel, Av. de Bellevaux 51, C.P. 2, CH-2007 Neuchâtel, Switzerland recently been shown to display remarkably strong trans effects. ${ }^{7}$ Here, we provide evidence for the formation of pyridylidene complexes using pyridinium ionic liquids as ligand precursors. Moreover these pyridylidene complexes actively catalyze Suzuki cross-coupling reactions.

Our approach towards pyridylidene complexes starts from nicotine as a versatile starting material. First, coordination of the pyrrolidine nitrogen should support the $\mathrm{M}-\mathrm{C}_{\text {carbene }}$ bond through chelate formation. Second, enantiopure nicotine is readily available and offers a cheap and convenient access to chiral complexes that may be useful for asymmetric catalysis. Thus, the pyridinium salt $\mathbf{1}$ has been prepared from nicotine by selective alkylation of the imine nitrogen with $i$ PrI. At room temperature, $\mathbf{1}$ is a highly viscous ionic liquid that dissolves readily in alcohols, though only sparingly in THF and $\mathrm{H}_{2} \mathrm{O}$. Palladation of $\mathbf{1}$ occurs smoothly at room temperature in the presence of $\left[\mathrm{Pd}(\mathrm{OAc})_{2}\right]$ and a base such as $\mathrm{KO} t \mathrm{Bu}$ (eqn. 1).
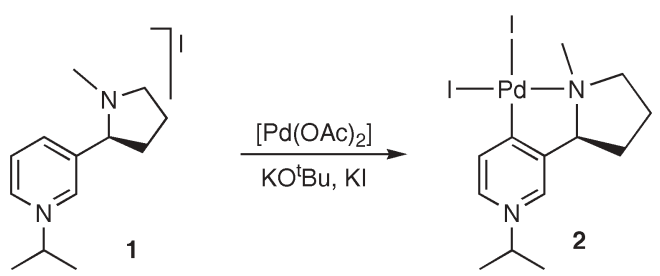

Contrary to our expectation, metallation takes place at the 4rather than at the most acidic 2-pyridinium position, thus affording the palladium complex $\mathbf{2}$ as an orange solid. $\dagger$ The observed regioselectivity of metallation possibly originates from the directing effects of the pyrrolidine substituent, ${ }^{8}$ though shielding of the ortho positions by the bulky isopropyl groups may also be effective.

The two low-field doublets at $\delta 8.69$ and 8.49 in the ${ }^{1} \mathrm{H}$ NMR spectrum of $\mathbf{2}$ are indicative for the protons ortho to the pyridine nitrogen and are therefore diagnostic for the site of metallation. Notably, we observed a long-range coupling between $\mathrm{H}^{2}$ and $\mathrm{H}^{5}$ $\left({ }^{5} J_{\mathrm{HH}}=1.7 \mathrm{~Hz}\right)$ that is relatively large, probably owing to the particular electronic configuration of the heterocycle.

The proposed structure of $\mathbf{2}$ was unequivocally confirmed by an $\mathrm{X}$-ray diffraction analysist of single crystals that were grown by slow diffusion of $\mathrm{Et}_{2} \mathrm{O}$ into a DMSO solution of 2 . The unit cell contains four independent molecules of $\mathbf{2}$, whose structures are mutually strongly related. The molecular structure (Fig. 1) reveals a palladium center in a slightly distorted square-planar environment defined by two iodide ligands and the $C, N$-bidentate chelating pyridylidene ligand. The most relevant features of the five-membered palladacycle - average bite angle $82.5(2)^{\circ}, \mathrm{Pd}-\mathrm{C}$

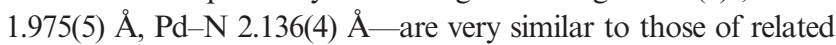




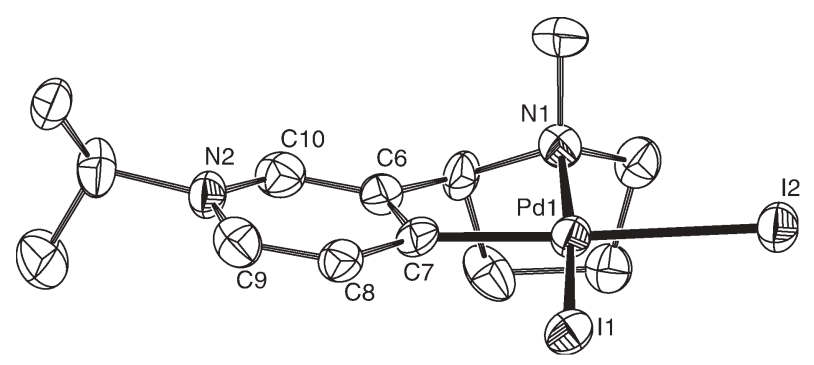

Fig. 1 ORTEP representation of $\mathbf{2}$ (one of the four independent molecules) with thermal ellipsoids at the $30 \%$ probability level, hydrogen atoms are omitted. Pertinent bond lengths $(\AA)$ and angles $\left({ }^{\circ}\right)$ : Pd1-C7 1.994(10), Pd1-N1 2.129(8), Pd1-I1 2.587(1), Pd1-I2 2.683(1); C7-Pd1N1 82.6(4), C7-Pd1-I1 93.2(3), C7-Pd1-I2 175.2(3), N1-Pd1-I1 173.5(2), I1-Pd1-I2 91.64(3).

chelating arylamine palladium complexes. ${ }^{9}$ Apparently, the metalcarbon bond length in these complexes is essentially defined by the chelating amine site. Hence, $\mathrm{Pd}-\mathrm{C}$ bond analysis does not provide any information on the metal-carbon bond strength. In contrast, the metal-iodide bonds represent useful probes for the trans influence of the pyridylidene site. The $\mathrm{Pd}-\mathrm{I}$ bond trans to carbon (average Pd1-I2 2.692(1) A) is significantly longer than the one trans to nitrogen (average Pd1-N1 2.589(1) $\AA$ ). The difference of $0.10 \AA$ A corresponds to a $3.7 \%$ bond stretching and indicates a trans influence of the pyridylidene ligand that is about as strong as the one observed in related imidazolylidene complexes. ${ }^{10}$

The pyridinium ring does not show any significant $\mathrm{C}-\mathrm{C}$ bond length alterations that could indicate a quinoidal pyridylidene structure in the solid state (eqn. 2). Conservation of the $\mathrm{sp}^{2}$ hybridization at the pyridine nitrogen would point to a zwitterionic structure with a highly dipolar resonance form, comprising a cationic pyridinium group and an anionic palladate rather than a neutral pyridylidene palladium complex (eqn. 2).
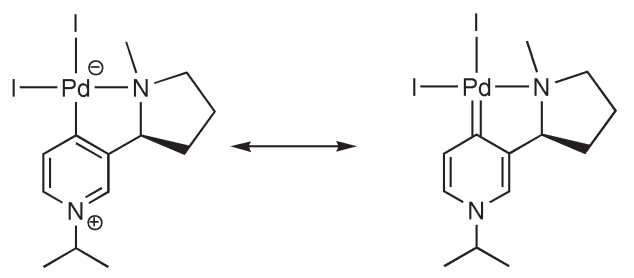

The ${ }^{13} \mathrm{C}$ NMR chemical shift of the palladium-bound carbon $\left(\delta_{\mathrm{C}}\right.$ 176.2), however, compares well with related heterocyclic carbenes $^{6,7}$ and suggests considerable carbene contribution to the bonding.

The pyridylidene complex $\mathbf{2}$ actively catalyzes the Suzuki coupling of aryl iodides and bromides with phenylboronic acids (eqn. 3).§

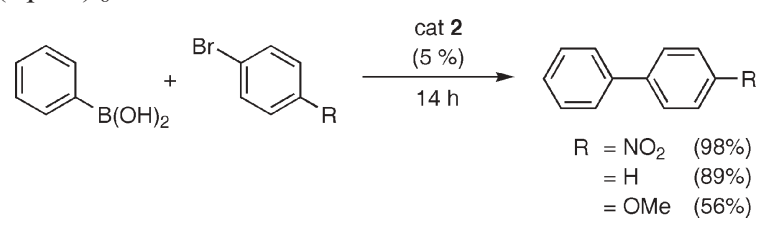

Conversions typically reach completion after $24 \mathrm{~h}$, which compares well with similar catalytic experiments performed with palladium salts in pyridinium ionic liquids. ${ }^{5}$ Addition of $\mathrm{Hg}^{0}$ to the reaction mixture gives $70 \%$ conversion, which shows that the reaction is at least predominantly homogeneous. ${ }^{11,12}$ Deactivated aryl bromides such as 4-bromoanisole are converted significantly slower (56\% after $24 \mathrm{~h})$ and aryl chlorides essentially fail (11\%), though optimization of reaction conditions may improve catalyst performance.

In conclusion, our results show that stable $N$-heterocyclic carbene complexes are readily accessible from pyridinium salts by base-promoted palladation. In view of the mild conditions for the formation of these novel palladium complexes and their activity in cross-coupling reactions, similar pyridylidene palladium complexes may be responsible for the observed catalytic activity when using palladium as catalyst precursor in pyridinium ionic liquids. Moreover, we have disclosed a new and cheap entry to chiral carbene complexes. Their performance in asymmetric catalysis is currently under investigation and will be reported in due course.

We thank the Swiss National Science Foundation for financial support (grant 200021-107802). M.A. gratefully acknowledges an Alfred Werner Assistant Professorship.

\section{Notes and references}

$\dagger$ Synthesis of 2: To a suspension of pyridinium salt 1 ( $0.81 \mathrm{~g}, 2.4 \mathrm{mmol})$ in dry THF $(20 \mathrm{~mL})$ was added $\mathrm{KO} t \mathrm{Bu}(0.27 \mathrm{~g}, 2.4 \mathrm{mmol})$ followed by $\mathrm{Pd}(\mathrm{OAc})_{2}(0.55 \mathrm{~g}, 2.4 \mathrm{mmol})$. After $1 \mathrm{~h}, \mathrm{KI}(1.66 \mathrm{~g}, 10 \mathrm{mmol})$ was added and the mixture was stirred for $2 \mathrm{~d}$ at room temperature. Volatiles were evaporated in vacuo, and the residue was purified by column chromatography $\left(\mathrm{SiO}_{2}, \mathrm{CH}_{2} \mathrm{Cl}_{2}\right.$ /acetone $\left.8: 1\right)$. The orange fraction was collected and evaporated to yield 2 as an orange solid $(0.36 \mathrm{~g}, 27 \%)$. An analytically pure sample of 2 was obtained by recrystallization from $\mathrm{CH}_{2} \mathrm{Cl}_{2}$ and pentane. Anal. found (calcd) for $\mathrm{C}_{13} \mathrm{H}_{20} \mathrm{I}_{2} \mathrm{~N}_{2} \mathrm{Pd}$ (564.54): C 27.67 (27.66), $\mathrm{H} 3.65$ (3.57); N 4.91 (4.96); Pd 18.83 (18.85). ${ }^{1} \mathrm{H}$ NMR (500 MHz, DMSO- $d_{6}$, $298 \mathrm{~K}) \delta 8.69\left(1 \mathrm{H}, \mathrm{d},{ }^{3} J=6.4 \mathrm{~Hz}, \mathrm{H}^{6}\right), 8.49\left(1 \mathrm{H}, \mathrm{d},{ }^{3} J=1.7 \mathrm{~Hz}, \mathrm{H}^{2}\right), 8.27$ $\left(1 \mathrm{H}, \mathrm{dd},{ }^{3} J=6.5 \mathrm{~Hz},{ }^{4} J=1.7 \mathrm{~Hz}, \mathrm{H}^{5}\right), 4.71\left(1 \mathrm{H}\right.$, sept, ${ }^{3} J=6.7 \mathrm{~Hz}$, $\left.\mathrm{CHMe}_{2}\right), 4.3(1 \mathrm{H}, \mathrm{br}, \mathrm{NCHH}), 4.09\left(1 \mathrm{H}, \mathrm{t},{ }^{3} J=8.5 \mathrm{~Hz}, \mathrm{pyCHN}\right), 3.74$ (s, $\left.3 \mathrm{H}, \mathrm{NCH}_{3}\right), 2.53\left(2 \mathrm{H}, \mathrm{m}, \mathrm{NCH} H, \mathrm{NCH}_{2} \mathrm{CH}_{2} \mathrm{CH} \mathrm{H}\right), 2.4(1 \mathrm{H}, \mathrm{m}$, $\left.\mathrm{NCH}_{2} \mathrm{CHH}\right), 2.0\left(2 \mathrm{H}, \mathrm{m}, \mathrm{NCH}_{2} \mathrm{CH} H, \mathrm{NCH}_{2} \mathrm{CH}_{2} \mathrm{CH} H\right), 1.55(3 \mathrm{H}, \mathrm{d}$, $\left.{ }^{3} J=6.7 \mathrm{~Hz}, \mathrm{CHMeCH}_{3}\right), 1.54\left(3 \mathrm{H}, \mathrm{d},{ }^{3} J=6.7 \mathrm{~Hz}, \mathrm{CHCH}_{3} \mathrm{Me}\right) ;{ }^{13} \mathrm{C}\left\{{ }^{1} \mathrm{H}\right\}$ NMR $\left(125 \mathrm{MHz}, \mathrm{DMSO}-d_{6}, 353 \mathrm{~K}\right) \delta 176.2(\mathrm{C}-\mathrm{Pd}), 155.2\left(\mathrm{C}^{3}\right), 140.0\left(\mathrm{C}^{5}\right)$, $135.7\left(\mathrm{C}^{6}\right), 132.0\left(\mathrm{C}^{2}\right), 76.5$ (pyCN), $62.0\left(\mathrm{CHMe}_{2}\right), 61.7\left(\mathrm{br}, \mathrm{NCH}_{2}\right), 47.3$ $\left(\mathrm{NCH}_{3}\right), 34.3\left(\mathrm{NCH}_{2} \mathrm{CH}_{2} \mathrm{CH}_{2}\right), 22.3\left(\mathrm{CHCH}_{3} \mathrm{Me}\right), 22.2\left(\mathrm{CHMeCH}_{3}\right), 21.8$ $\left(\mathrm{NCH}_{2} \mathrm{CH}_{2}\right)$.

t Crystal data for 2: Empirical formula $\left[\mathrm{C}_{13} \mathrm{H}_{20} \mathrm{I}_{2} \mathrm{~N}_{2} \mathrm{Pd}\right], M$ 564.51, orange rod, orthorhombic, space group $P 2_{1} 2_{1} 2_{1}$ (no. 19), $a=12.7386(6)$, $b=16.3024(8), c=31.923(2) \AA, V=6629.4(6) \AA^{3}, Z=16, \mathrm{D}_{\mathrm{c}}=$ $2.262 \mathrm{~g} \mathrm{~cm}^{-3}$, MoK $\alpha$ radiation, $\lambda=0.71073 \AA, T=153(2) \mathrm{K}$, $2 \theta_{\max }=52.2^{\circ}, 50877$ reflections measured, 13031 unique $\left(R_{\text {int }}=0.0882\right)$. Final $G o o F=0.944, R 1=0.0423, w R 2=0.0853, R$ indices based on 9801 reflections with $I>2 \sigma(I)$ (refinement on $F^{2}$ ), 661 parameters, 0 restraints, Flack parameter $=0.01(3)$. Lp and absorption corrections applied, $\mu=4.832 \mathrm{~mm}^{-1}$. CCDC 275134. See http://dx.doi.org/10.1039/b508225k for crystallographic data in CIF or other electronic format.

$\S$ General Suzuki procedure: To a solution of phenylboronic acid $(0.55 \mathrm{mmol})$ and aryl bromide $(0.50 \mathrm{mmol})$ in DMSO $(3.0 \mathrm{~mL})$ were added bis(ethylene glycol) dibutyl ether $\left(0.25 \mathrm{mmol},{ }^{1} \mathrm{H}\right.$ NMR standard $)$ and aqueous $\mathrm{K}_{2} \mathrm{CO}_{3}\left(1.2 \mathrm{mmol}\right.$ dissolved in $\left.1.2 \mathrm{~mL} \mathrm{H}_{2} \mathrm{O}\right)$, followed by 2 (100 mg, $25 \mu \mathrm{mol})$ as a DMSO solution ( $2.5 \mathrm{mmol}$ in $10 \mathrm{~g} \mathrm{DMSO}$ ). The reaction mixture was stirred at $100{ }^{\circ} \mathrm{C}$. Aliquots were taken from the reaction mixture, suspended into aqueous $\mathrm{KOH}(5 \mathrm{~mL})$ and extracted with $\mathrm{Et}_{2} \mathrm{O}(3 \times 5 \mathrm{~mL})$. The combined organic fractions were washed with brine $(8 \mathrm{~mL})$, dried $\left(\mathrm{Na}_{2} \mathrm{SO}_{4}\right)$, and evaporated to dryness. The residue was filtered through a short pad of $\mathrm{SiO}_{2}\left(\mathrm{Et}_{2} \mathrm{O}\right.$ as eluent), evaporated to dryness, and analyzed by ${ }^{1} \mathrm{H}$ NMR.

1 T. Welton, Chem. Rev., 1999, 99, 2071; P. Wasserscheid and W. Keim, Angew. Chem., Int. Ed., 2000, 39, 3772; J. Dupont, R. T. de Souza and P. A. Z. Suarez, Chem. Rev., 2002, 102, 3667.

2 C. C. Cassol, A. P. Umpierre, G. Machado, S. I. Wolke and J. Dupont, J. Am. Chem. Soc., 2005, 127, 3298.

3 D. Bourissou, O. Guerret, F. P. Gabbaï and G. Bertrand, Chem. Rev., 2000, 100, 39; W. A. Herrmann, Angew. Chem., Int. Ed., 2002, 41, 1290. 
4 S. Gründemann, M. Albrecht, A. Kovacevic, J. W. Faller and R. H. Crabtree, J. Chem. Soc., Dalton Trans., 2002, 2163;

D. S. McGuinness, K. J. Cavell, B. F. Yates, B. W. Skelton and A. H. White, J. Am. Chem. Soc., 2001, 123, 8317.

5 D. Zhao, Z. Fei, T. J. Geldbach, R. Scopelliti and P. Dyson, J. Am. Chem. Soc., 2004, 126, 15876.

6 B. Crociani, F. Di Bianca, A. Giovenco and A. Scrivanti, J. Organomet. Chem., 1983, 251, 393; B. Crociani, F. Di Bianca, A. Giovenco and A. Scrivanti, J. Organomet. Chem., 1986, 269, 295; G. R. Newkome, D. W. Evans and F. R. Fronczek, Inorg. Chem., 1987, 26, 3500.

7 J. S. Owen, J. A. Labinger and J. E. Bercaw, J. Am. Chem. Soc., 2004, 126, 8247
8 A. J. Meyers and R. A. Gabel, J. Org. Chem., 1982, 47, 2633.

9 For examples, see: J.-M. Valk, F. Maassarani, P. van der Sluis, A. L. Spek, J. Boersma and G. van Koten, Organometallics, 1994, 13, 2320; G. LeBorgne, S. E. Bouaoud, D. Grandjean, P. Braunstein, J. Dehand and M. Pfeffer, J. Organomet. Chem., 1977, 136, 375.

10 J. A. Loch, M. Albrecht, E. Peris, J. W. Faller and R. H. Crabtree, Organometallics, 2002, 21, 700.

11 D. R. Anton and R. H. Crabtree, Organometallics, 1983, 2, 855.

12 Heterogeneous Pd has been reported to catalyze Suzuki reactions. For examples, see: J. Tsuji, Palladium Reagents and Catalysts, Wiley-VCH, Weinheim, 2004, p. 293. 